\title{
Література
}

1. Березина Л. В. К вопросу о развитии познавательной активности студентов неязыковых факультетов при обучении русскому языку / Л. В. Березина // Вестник Дагестанского научного центра Российской академии образования. - 2012. - № 3. - С. $28-32$. 2. Венгер О. П. Психолого-педагогічні особливості розвитку пізнавальної діяльності студентів вищого навчального закладу: дис. ... канд. психол. наук: 19.00.07. / Венгер О. П. Острог, 2014. - 225 с. 3. Зайченко І. В. Педагогіка: [навч. посіб. для студентів вищ. навч. закл.] / І. В. Зайченко. - [2-ге вид.]. - Київ: Освіта України: КНТ, 2008. - 526 с. 4. Максименко С. Д. Загальна психологія. [навч. посіб.] / С. Д, Максименко. - [3-є вид., перероб. і доп.]. - Київ : Центр учбової літератури, 2008. - 272 с. 5. Методика навчання української мови в середніх освітніх закладах / кол. авторів за ред. М. І. Пентилюк: М. І. Пентилюк, С. О. Караман, О. В. Караман, О. М. Горошкіна, З. П. Бакум та ін. - Київ : Ленвіт, 2009. - 399 с. 6. Основи загальної психології: [навч. посіб.: У 2-х т.] / укл. : Полозенко О. В., Омельченко Л. М., Яшник С. В., Свистун В. І. та ін. - Київ : НУБіП, 2009. Т. 1. - 322 с. 7. Плиско К. М. Теорія і методика навчання української мови в середній школі / К. М. Плиско. - Харків, 1995. - 83 с. 8. Практикум з методики навчання української мови в загальноосвітніх закладах: модульний курс: [посіб. для студентів пед. університетів та інститутів] / кол. авторів за ред. М. І. Пентилюк. - Київ : Ленвіт, 2011. - 366 с. 9. Психологія / [ред. Г. С. Костюк]. - Київ : Рад. школа, 1968. - 568 с. 10. Рубинштейн С. Л. Основы общей психологии / С. Л. Рубинштейн. - Санкт-Петербург : Питер, 1999. - 720 с. 11. Сорокун П. А. Основы психологии : [учеб. пособие]/ П. О. Сорокун. - Псков: ПГПУ, 2005.- 312 с. 12. Яремчук Н. С. Система роботи з удосконалення говоріння в учнів 5-6 класів на уроках української мови: дис. ... канд. пед. наук: 13.00.02. / Яремчук Наталія Сергіївна. - Херсон, 2009. - 245 c.

УДК 378.046.4: 378.048.2

Наталія Зеленкова, Ксенія Морозова

\section{ОРГАНІЗАЦІЯ ВІДКРИТОГО НАВЧАЛЬНОГО СЕРЕДОВИЩА ЯК ДИДАКТИЧНА УМОВА РОЗВИТКУ ІНФОРМАЦЙНО-КОМУНІКАЦЙНИХ КОМПЕТЕНТНОСТЕЙ МАГІСТРАНТІВ У ПРОЦЕСІ ВИВЧЕННЯ ПСИХОЛОГО-ПЕДАГОГІЧНИХ ДИСЦИПЛІн}

Зеленкова Н. І., Морозова К. О. Організація відкритого навчального середовища як дидактична умова розвитку інформаційно-комунікаційних компетентностей магістрантів у процесі вивчення психолого-педагогічних дисциплін.

У статті проаналізовано поняття «відкрите навчальне середовище». Розкрито особливості реалізації такого середовища як однієї 3 дидактичних умов розвитку інформаційно-комунікаційних компетентностей магістрантів.

Ключові слова: інформаційно-комунікаційні компетентності, відкрите навчальне середовище, дидактична умова.

Зеленкова Н. И., Морозова К. А. Организация открытой учебной среды как дидактическое условие развития информационно-коммуникационных компетентностей магистрантов в процессе изучения психолого-педагогических дисциплин.

В статье проанализировано понятие «открытая учебная среда». Раскрыты особенности реализации такой среды как одного из дидактических условий развития информационно- 
коммуникационных компетенций магистрантов.

Ключевые слова: информационно-коммуникационные компетентности, открытая учебная среда, дидактическое условие.

Zelenkova N. I., Morozova K. A. Open learning environment as a didactic condition for the development of masters' information and communication competences in teaching psychological and pedagogical subjects.

The concept of «open learning environment» is analyzed. The implementation features of such an environment as one of the didactic conditions for the development of masters' information and communication competencies are revealed.

Key words: information and communication competences, open learning environment, didactic condition.

Головною вимогою реалізації компетентнісного підходу в підготовці магістрантів як майбутніх наукових кадрів стає проектування і реалізація таких технологій навчання, які б створювали ситуації залучення студентів до різних видів діяльності.

Ураховуючи специфіку дослідження, а саме пріоритетність компетентнісного підходу, який передбачає інтегрування інноваційних технологій у навчально-виховний процес, а також будучи зорієнтованим насамперед на нове бачення мети та оцінювання результатів навчання, висуває свої вимоги і до інших компонентів освітнього процесу, а саме: до змісту, педагогічних технологій, засобів контролю й оцінки, відзначимо, що одним із головних напрямків розвитку впровадження будь-яких нових технологій, зокрема IКТ, є надання викладачеві й студентові права вільного вибору технологій навчання, форм і методів роботи, що впливає на результативність через урізноманітнення можливостей подання навчального матеріалу й організації навчально-виховного процесу загалом з урахуванням особливостей кожного зі студентів [1-4].

Mета статmі: рокрити особливості реалізації відкритого навчального середовища як дидактичної умови розвитку інформаційно-комунікаційних компетентностей магістрантів.

Із визначення ІК-компетентності випливає, що така якість особистості передбачає засвоєння магістрантами не окремих елементів знань та умінь, які не пов'язані одне з одним, а оволодіння ними комплексною процедурою розв'язання професійних, педагогічних i завдань іншого характеру, оскільки в побудові навчального процесу на основі компетентнісного підходу студентам ставиться проблема, яка передбачає самостійне здійснення цільового пошуку потрібних відомостей та формування дій щодо розв'язування таких завдань [1-3]. Задля реалізації окресленого процесу необхідним $\epsilon$ створення особливого простору навчально-пізнавальної діяльності, де магістранти будуть залучені до колективного пошуку істини, зможуть сформувати та аргументувати власну позицію, а також толерантно ставитися до альтернативних думок і застосовувати власний досвід для виконання тих чи тих завдань. Таку можливість надає відкрите навчальне середовище (НС), організація, формування та застосування якого передбачається у відкритих педагогічних системах. У відкритому НС широко використовуються комп'ютерні навчальні програми різного призначення, здійснюється адресне постачання й обмін електронними інформаційними ресурсами, забезпечується дистанційне спілкування учасників навчального процесу та організаторів освіти тощо [2-4].

3 огляду на те, що магістрантів готують до розв'язання специфічних професійних завдань, зокрема й інноваційного, педагогічного характеру, особливістю їх самостійної 
навчальної діяльності визначаємо спрямованість на результативність роботи, усвідомлення й систематизацію навчального матеріалу, набуття певного досвіду. Ураховуючи специфіку дослідження - розвиток ІКК магістрантів - нагальною потребою постає застосування студентами під час самостійної роботи відповідних засобів та елементів ІКТ. Практична частина нашого дослідження грунтується на дисциплінах психолого-педагогічного циклу, що зумовлює можливість лише опосередкованого впливу на інформаційно-комунікаційні компетентності студентів у процесі навчання, при цьому поєднання матеріалу з IКТ має задовольняти такі вимоги:

компетентностей;

- інформація має бути цікавою, актуальною, стимулювати розвиток IК-

- інформація повинна бути професійно спрямованою.

Необхідність упровадження ІКТ та розвитку у студентів відповідних компетентностей щодо роботи з такими технологіями продиктована й основними завданнями Болонського процесу - створення міжнародного глобального освітнього середовища, головною перевагою якого є подання навчального матеріалу в дидактично уніфікованому й формалізованому вигляді і створення умов використання його контенту в будь-якому місці та в будь-який час [3-5]. Акцентуємо увагу на поступовому залученні студентів до місцевих електронних ресурсів з дисципліни, вироблення у них поняття та усвідомлення можливостей і переваг такого варіанту подання та збереження інформації, а також оптимізації їхньої навчальної діяльності (аудиторної та самостійної).

Особливості концептуального призначення та використання відкритого навчального середовища розкрито в дослідженні В. Бикова. Науковець наголошує, що реалізація принципів відкритої освіти, використання сучасних методів і засобів інформаційнокомунікаційних технологій (IКТ) дозволяють суттєво розширити потенційний простір навчального середовища (НС), що передусім стосується доступної якісної та кількісної множини інформаційних ресурсів, можливих для застосування в навчально-виховному процесі завдяки розподіленим автоматизованим банкам даних і знань, та обчислювальних ресурсів, що пропонуються і підтримуються в комп’ютерних мережах [1-3].

Включення до системи освіти таких технологій дозволяє ефективно реалізувати як загальнодидактичні (освітня, виховна, розвивальна), так і вузькоспеціальні цілі, розвивати пізнавальні інтереси, сприяти інтелектуальному зростанню [3]. Навчально-виховний процес, який грунтується на сучасних інформаційно-комунікаційних технологіях, створює передумови для розвитку принципово нової культури організації навчання.

Закцентуємо увагу на деяких думках І. Ставицької, яка стверджує, що упровадження IКТ у сучасну освіту сприяє накопиченню та обміну технологічним і соціальним досвідом, а також комфортній адаптації до майбутньої професійної та інших видів діяльності особистості [3-5].

Використання нових інформаційних технологій надає змогу створити на занятті комфортне середовище, допомагає розбудити творчі начала в студентах, сприяє розвитку критичного мислення та формує відповідні професійні навички. При цьому змінюється парадигма навчання: більше уваги приділяється виробленню увмінь самостійно здобувати знання в умовах дослідницької діяльності. Застосування IКT у навчанні посилює міжпредметні зв'язки, що сприяє налагодженню відношень між державними стандартами освіти. Відкрите навчальне середовище з дисципліни сприяє розвитку у студентів потреби в розширенні та поглибленні своїх знань, умінні зважено приймати рішення та відповідати за їх наслідки, що є невід'ємним складником виховання гармонійно розвиненої особистості, а 
також чинником розвитку інформаційно-комунікаційних компетентностей студентів, акцентуючи при цьому увагу не на IКТ як предметі діяльності, а на ІКТ як на допоміжному засобі опанування навчальним матеріалом.

Навчальний процес, як відомо, це система, яка охоплює такі складники: цільовий (усвідомлення і прийняття цілі та завдань окремої теми, розділу або дисципліни загалом), стимулюючо-мотиваційний (стимулювання педагогом пізнавального інтересу, сприяння мотивації навчальної діяльності), змістовий компонент (визначається навчальним планом та навчальною програмою), операційно-діяльнісний (реалізується за допомогою певних форм та методів організації навчання), контрольно-регулюючий (розроблення та проведення усних, письмових, лабораторних та інших робіт, опитувань, заліків, семінарів та іспитів), оцінно-результативний (оцінювання педагогами та самооцінювання студентами навчальних досягнень та результатів, встановлення відповідності їх поставленим навчально-виховним цілям). Кожен із окреслених складників передбачає наявність взаємозв'язків з іншими, тому застосування інформаційно-комунікаційних технологій в одному секторі аналізованої системи формує доцільність застосування таких технологій в іншому. Розглядаючи навчально-виховний процес у такому контексті, можна говорити про загальну його інформатизацію шляхом організації відкритого навчального середовища, яке сприяє збільшенню евристичного складника навчального процесу за рахунок застосування інтерактивного навчання та мультимедійних засобів навчального призначення, використання телекомунікаційних методів конструювання знань, набуття учнями досвіду електронного спілкування з усім світом [2-3].

Відтак першою дидактичною умовою розвитку інформаційно-комунікаційних компетентностей магістрантів у процесі вивчення психолого-педагогічних дисциплін постає організація відкритого навчального середовищза з дисципліни.

Означена умова передбачає розроблення й систематичне застосування навчального web-pecyрсу з дисципліни, зокрема для самостійної навчальної діяльності, використання спеціалізованих методичних вказівок для студентів, які не зорієнтовані на інформаційні технології як на фах, щодо застосування елементів ІКТ у процесі вивчення психологопедагогічних дисциплін для поліпшення сприйняття навчального матеріалу та розвитку в них відповідних компетентностей. Така умова $є$ чинником, який покращить самостійну навчальну роботу магістрантів, сформує в них відповідні навички роботи з електронними ресурсами, дозволить зберігати необхідний обсяг навчальної інформації в комплексі на одному сайті, не перенавантажуючи таким чином студентів зайвими інтернет-сервісами.

Закцентуємо увагу на можливих варіантах реалізації означеної дидактичної умови в межах змішаного навчання:

1) Face - to - Face Driver («Драйвер - очна освіта») - викладач особисто дає основний обсяг навчального плану, за необхідності додаючи онлайн-навчання;

2) Rotation Model («Ротаційна модель») - відбувається ротація розкладу традиційного очного навчання та самостійного онлайн-навчання (наприклад, через Інтернет за планом посилань, складеним викладачем. в blended-програмі чи на спеціальному сайті);

3) Flex Model («Гнучка модель») здебільшого використовується онлайн-платформа, викладач підтримує студентів у міру потреби, час від часу працює з невеликими групами;

4) Online Lab («Онлайн-лабораторія») - онлайн-платформа використовується для передачі всього курсу на заняттях. Відбувається таке навчання під наглядом викладача;

5) Self-Blend Model («Змішай сам») - студент вирішує, які з Brick and Mortar - курсів йому необхідно доповнити віддаленими онлайн-заняттями; 
6) Online Driver Model («Драйвер - онлайн-навчання») передбачає навчання он-лайн через платформу і віддалений контакт з викладачем [4-5].

Ураховуючи те, що пропоноване дослідження грунтується на викладанні психологопедагогічних дисциплін у магістратурі, коли значний обсяг навчального матеріалу припадає на самостійне опрацювання, найбільш оптимальними вважаємо поєднання та циклічне застосування таких моделей навчання, як Face-to-Face та Driver Rotation Model.

Отже, вплив на розвиток ІКК магістрантів має бути систематичним та враховувати особливості їхньої освітньої діяльності. Навчальний матеріал із психолого-педагогічних дисциплін досить різноплановий та творчий, тому у процесі навчання студентам необхідно виявляти уміння мислити, робити висновки, розв'язувати проблемні завдання, пропонувати власні варіанти дій. У поєднанні з ІКТ цей процес може стати мінливим, адже означений цикл не можна повністю інформатизувати, доцільним $\epsilon$ використання лише окремих елементів IКТ у методах, формах навчання, а також застосування певних ІКТ-засобів.

\section{Література}

1. Биков В. Ю. Моделі організаційних систем відкритої освіти: [монографія]. - Київ : Атіка, 2008. - 684 с. 2. Биков В. Ю. Навчальне середовище сучасних педагогічних систем // Личность в Едином образовательном пространстве: [сб. науч. статей I Междунароного образовательного форума] (г. Запорожье, 5-7 мая 2010 г.)/ под науч. ред. проф. К. Л. Крутий. - Часть 2. -Запорожье : $\quad$ ООО «ЛИПС» ЛТД, 2010. - $\quad$ С. 234-243. 3. Жалдак М. І. Інформатика - фундаментальна наукова дисципліна. Вона має вивчати закони природи, інформаційні процеси і відповідні технології / М. І. Жалдак // Комп’ютер у школі та сім’ї. - 2010. - № 2. - С. 39-43. 4. Завдання Болонської декларації [Електронний pecypc]. - Режим доступу : http://eduknigi.com/ped_view.php?id=7 5. Зимняя И. А. Ключевые компетентности как результативно-целевая основа компетентностного подхода в образовании / Ирина Алексеевна Зимняя. - Москва: Исследов. центр проблем качества подготовки специалистов, 2004. - 40 с. 6. Кліх Л. В. Становлення магістратури в системі вищої освіти України / Л. В Кліх // Науковий вісник Національного університету біоресурсів i природокористування України. Серія: Педагогіка, психологія, філософія. - 2011.Вип. 159. - Част. 3. - С. 72-79.

Інга Сіняговська

\section{ПРОБЛЕМА ІНТЕРІОРИЗАЦІЇ ЗНАНЬ У ПСИХОЛОГО-ПЕДАГОГІЧНІЙ НАУЦІ}

Сіняговська І. Ю. Проблема інтеріоризації знань у психолого-педагогічній науці.

У статті розглянуто та проаналізовано основні положення дослідження проблеми інтеріоризації знань у психолого-педагогічній науці. Окреслено основні методологічні підходи до дослідження феномену. Проаналізовано зміст понять «інтерналізація», «інтеріоризація», «інтеріоризація знань».

Ключові слова: інтерналізація, інтеріоризація, інтеріоризація знань, навчальна діяльність, методологічні підходи.

Синяговская И. Ю.Проблема интериоризации знаний в психолого-педагогической науке.

В статье рассмотрены и проанализированы основные положения исследования проблемы интериоризации знаний в психолого-педагогической науке. Обозначены основные 